\title{
XVIII. Extract from a memoir on a new metal called tellurium
}

\section{Professor Klaproth}

To cite this article: Professor Klaproth (1798) XVIII. Extract from a memoir on a new metal called tellurium , Philosophical Magazine Series 1, 1:1, 78-82, DOI: $10.1080 / 14786447808676799$

To link to this article: http://dx.doi.org/10.1080/14786447808676799

$$
\text { 曲 Published online: } 04 \text { Mar } 2010 .
$$

Submit your article to this journal $\lceil\pi$

III Article views: 11

Q View related articles $₫$ 
and the cork $\mathrm{L}$, to which the two former are faftened. At $e$ is a piece of lead, which ferves at the fame time to adjuft the weight of the ball, and to keep it in an upright pofition.

Fig. 3 is a plan of the cork, fhowing the apertures through which the liquor defcends. The tubes $D$ and $F$ are each in two parts, joined by pieces of elaftic gum, by which means the apparatus admits of being moved without danger of breaking. There is alfo a glafs rod $e$ in the veffel $A$ for the purpofe of ftirring the materials. This rod paffes tight through a piece of gum elaftic (the mouth end of one of the common bottles made of that fubitance), the other end of which is fitted clofe to the mouth of the veffel A, by means of wire or catgut wound round it, to prevent the efcape of the gas.

XVIII. Extract from a Memoir by Profeffor KLAPRoTh, on a new Metal called Tellurium, read in a public Sitting of the Academy of Sciences at Berlin, Jan. 25tb, 1798 .

P fis the ore of the auriferous mine known under the denomination of the mine of white gold, aurum paradoxum, metallum zel aurum problematicum*, found in that mineral a metal abfolutely different from any hitherto known, and to which he gave the name of tellurium, as a companion to the uranium and titanium, new metals difcovered fome time ago by the fame chemift. M. Muller of Reichenftein had, fo early as 1782 , fufpected that this ore contained a peculiar metallic fubftance, and his fufpicion was confirmed by Bergman, to whom he had fent fome of the ore; but an account of the fmall quantity with which he had made his experiments he would not venture to decide, whether it contained 2 new

- This ore is found in the mine called Mariahilf in the Fatzbay mountain near Zalethna in Transylvania. See Emmerling Elemens de Mineralogit, t. xi. p. j24, 
metal, or whether what had been taken for a particular kind of metal might not be only antimony. The repeated and ingenious experiments made by $\mathrm{M}$. Klaproth on a nore confiderable quantity of the ore, which had been tranfmitted to him by M. do Reichenftein, fully confirmed the conjectures of the latter as well as thofe of Bergman.

\section{Process for obtaining the Metal from the Ore.}

x. The ore is gently heated with fix parts of the muriatic acid; three parts of the nitric acid being then added, the mixture is boiled; upon which there arifes a very confiderable efferwefence, and a complete folution is obtained.

2. The filtered folution is diluted with as much water as it can bear without becoming turbid, which is a very fmall quantity, and a folution of cauftic potafh is then added to the liquor, un il the white precipitate which is at firt formed difappears again, and nothing remains but a brown flaky fediment.

3. This laft precipitate is the oxyde of gold mixed with the oxyde of iron, and a feparation is effected by the common means.

4. The muriatic acid is added to the alkaline folution (2) in fufficiznt quantity to faturate the alkali entirely: an excefs of the acid mut be avoided. A white precipitate, which, by heat, fettles at the bottom of the veffel under the form of a heavy powder, is produced in great abundance. After the precipitate has been wahlied and dried, it is formed into a kind of paite with a fufficient quantity of any fat oil ; and this mafs is put into a fmall glafs retort, to which a recipient is nightly fitted. When this arrangement is made, it is gradually brought to a red heat; and in proportion as the oil is decompofed, there are obferved, as in the ditillation of mercury, brilliant and metallic drops which cover the upper part of the retort, and which, at intervals, fall to the bottom of the veflel, and are immediately replaced by others. After it has cooled, metallic fixed drops are found adhering to the fides of the retort and at the bottom of the veffel, and the 
remainder of the metal reduced and melted with a brilliant. furface, and almoft always cryftallized.

\section{Effential cbarakterzing Marks of tbis new Metal.}

$x$. It bas the white colour of tin, approaching to the gray colour of lead. Its metallic fplendour is confiderable, and its fracture laminated. It is highly brittle and friable. By fuffering it to cool quictly and gradually, it readily affumes a eryftallized furface.

2. Its fpecific gravity is 6.115 .

3. It belongs to the clafs of the moft fufible metals.

4. When heated by the blow-pipe upon charcoal, it burns with a very lively flame of a blue colour, inclining at the edges to green. It is fo volatile as to rife entirely in a whitifh gray fmoke, and exhales a difagreeable odour like that of radithes. On ceafing to heat it, without having entirely volatilized the fmall portion fubjected to this operation, the button which remained, retained for a long time its liquidity, and, by cooling, was covered with a radiated vegetation.

5. This metal amalgamates eafily with mercury.

6. With fulphur it forms a gray fulphure of a raditated frueture.

7. A folution of it in the nitric acid is tranfparent and colourlefs. When concentrated, it produces, in time, fmall white light cryftals, in the form of needles, which exhibit a dendritic aggregation.

8. The new metal diffolves in the nitro-muriatic acid. When a large quantity of water is added to fuch a faturated olution, the metal is precipitated in the ftate of an oxyde, under the form of a white powder, which, in this ftate, is foluble in the muriatic acid.

9. By mixing cold, in a well-ftopped veffel, a fmall quantity of this metal with a hundred times its weight of concentrated fulphuric acid, the latter gradually affumes a beautiful crimfon red colour. By means of a fmall quantity of water added, drop by drop, the colour difappears, and the 
finall quantity of the metal diffolved, depofits itfelf under the form of black flakes. Heat deftroys the folution: it makes the red colour difappear, and difpofes the metal to feparate in the ftate of a white oxyde.

Io. When, on the other hand, the concentrated falphuric acid is diluted with two or three parts of water, and a fmall quantity of the nitric acid has been added, a confiderable quantity of the metal will then be diffolved. The folution is tranfparent and colourlefs, and is not decompofed by the mixture of a larger quantity of water.

II. All the pure alkalis precipitate from acid folutions of this metal an oxyde, of a white colour, foluble in all acids: by an excefs of alkali, the precipitate which is formed is entirely re-diffolved. If carbonate be employed inftead of pure alkali, the fame phenomenon takes place-with this difference, however, that, by excefs of the latter, the precipitate formed is re-diffolved only in part.

12. Exceedingly pure pruftiate of potafh produces no precipitate in folutions of this metal.

13. Alkaline fulphurets mixed with acid folutions occafion a brown or blackifh precipitate, according as the metal is combined with more or lefs oxygen. It fumetimes bappens that the colour of the precipitate has a perfect refemblance to mineral kcrmes, or red fulphurated oxyde of antimony.

When the fulphuret of tellurium is expofed on burning charcoal, the metal burns with a blue culvur conjointly with the fulphur.

14. The infufion of gall-nuts, combined with the fame folutions, gives birth to a flaky precipitate of an Ifabella culour.

5. Iron and zine precipitate tellurium from its acid folutions in a metallic ftate, under the form of fmall black flakes, which refume their fplendour by friction, and which, on burning charcoal, melt into a metallic button.

Vol. I.

G 16. Tin 
16. Tin and antimony produce the fame phenomenon with the acid folutions of the new metal.

The precipitate formed by the antimony proves, in a friking manner, that tellurium is not a difguifed antimony, as has been fuppofed. A folution of tin in the muriatic acid, mixed with a folution of tellurium in the fame acid, produced alfo a black and metallic precipitate.

17. The oxyde of tellurium, obtained from acid folutions by alkalis, or from alkaline folmions by acids, are both reduced with a rapidity refembling detonation, when they are expofed to heat on charcoal. It burns, and is volatilifed, as has been already mentioned.

18. By heating for fome time this oxyde of tellurium in. a retort, it melts, and appears, after cooling, with a yellow ftraw colour, having acquired a fort of radiated texture.

19. Mixed with fat bodies, the oxyde of tellurium is perfectly reduced by the method above pointed out.

The ore of white gold of Fatzebay, aurum vel melallum problematicum, contains : tellurium 925.5 , iron $; 2.0$, gold 2.5. total 1000.0.

The graphic gold of Offenbanya contains: tellurium 60, gold 30, filver 10: total 100.0 .

Ore from the mine known under the name of the yellow mine of Nagyag contains : tellurium 45 , gold 27 , lead 19.5 , filver 8.5 , fulphur one atom: total 100.0 .

Ore from the mine known by the name of the mine of gray foliated gold of Nagyag contains: lead 50, tellurium 3.3 , gold 85 , fulphur 7.5 , fliver and copper 1 : total 1000 